\title{
Konvergencia vagy divergencia
}

\section{Merre tart Kelet-Közép-Európa és a FÁK mezőgazdasága?}

Kelet-Közép-Európa és a Szovjetunió mezőgazdaságának vizsgálata meglehetősen gyakori kutatási területnek számított az 1970-es és az 1980-as években. A régió mezőgazdasága a rendszerváltás után a nemzetközi kutatások egyik kulcsfontosságú témájává lépett elő, amelyet a „mezőgazdasági átmenet” címszó alatt vizsgáltak. A 2000-es évektől azonban a régió mezőgazdaságának vizsgálata egyre kevésbé érdekes kutatási területnek számít a nemzetközi szakirodalomban. A cikk célja, hogy Kelet-Közép-Európa és a Független Államok Közössége mezőgazdaságának teljesítményét vizsgálja 1997 és 2016 között annak érdekében, hogy megállapítsa, vajon az átmenet és az EU-csatlakozás hozott-e bármilyen konvergenciát a mezőgazdasági termelékenységben a régi tagállamok (EU15) szintjéhez képest. Ehhez a cikk a konvergenciaelméleteket hívja segítségül, valamint a Kernel-sürüség-függvényt és az átmeneti valószínüségek Markov-függvényeit alkalmazza állításai alátámasztására. Az eredmények szerint a vizsgált időszakban a két régió mezőgazdasága csak korlátozott mértékben tudott felzárkózni a nyugat-európai mezőgazdaság termelékenységéhez, és a jelentős termelékenységbeli különbség továbbra is megmaradt ezen a téren. A tendenciák hátterében sokféle ok húzódik meg, amelyeket a szerzők a cikk végén mutatnak be.* Journal of Economic Literature (JEL) kód: Q18.

A kelet-közép-európai országok (KKE) és a Független Államok Közösségének (FÁK) mezőgazdasági szektorai számos változáson mentek keresztül a Szovjetunió felbomlása óta. Egyrészt, mindkét régió áttért a piacgazdaságra, ami nagymértékben érintette az agráriumot is. Másrészt, 11 KKE-ország csatlakozott az Európai Unióhoz 2004-ben,

* A cikk az OTKA 112394. számú, 10 év EU-tagság - Az új tagországok tapasztalatai az agrárszektorban című kutatási projekt támogatásával készült. A cikk egy korábbi, kezdetleges változata prezentációként megjelent a Világbank által Washingtonban 2018. június 12-15. között megrendezett, Disruptive Innovations, Value Chains, and Rural Development című konferencián.

Csáki Csaba emeritus professzor, BCE (e-mail: csaba.csaki@uni-corvinus.hu).

Jámbor Attila egyetemi docens, BCE Agrárközgazdasági és Vidékfejlesztési Tanszék (e-mail: attila.

jambor@uni-corvinus.hu).

A kézirat első változata 2018. augusztus 15-én érkezett szerkesztőségünkbe.

DOI: http://dx.doi.org/10.18414/KSZ.2018.10.1048 
2007-ben és 2013-ban, ${ }^{1}$ megnyitva ezzel a régió számára a közös piacot, annak minden mezőgazdasági vonatkozásával. Harmadrészt, Oroszország szerepe nagymértékben megváltozott mind politikai, mind gazdasági szempontból az elmúlt közel három évtizedben, befolyásolva ezzel a FÁK mezőgazdaságai szektorait is.

A fenti változások ellenére a KKE és a FÁK mezőgazdasági szektorainak hosszú távú teljesítményét vizsgáló elemzések alapvetően egyaránt hiányoznak a nemzetközi és a hazai szakirodalomból, illetve a meglévő elemzések csak egyes elemeit adják viszsza a teljes folyamatnak. A cikk célja, hogy átfogó képet adjon a KKE és a FÁK mezögazdaságának hosszú távú teljesítményéről, és bemutassa, vajon milyen mértékü volt a konvergencia az EU15 vonatkozó teljesítményéhez képest.

A cikk felépítése a következő: a bevezetést a szakirodalom áttekintése követi, majd a módszertan bemutatása következik. Az általános tendenciák néhány alapvető leíró statisztikájának bemutatását a termelékenységalapú konvergenciavizsgálatok eredményeinek ismertetése követi. A cikk ezután a különbözö teljesítmények mögött rejlő lehetséges okokat elemzi, majd összegzi az eredményeket.

\section{Szakirodalmi áttekintés}

A téma jellegéből adódóan a szakirodalmi áttekintés három részből áll. Az első két rész röviden bemutatja a két vizsgált régió mezőgazdasági teljesítményéhez kapcsolódó fontosabb cikkeket, a harmadik pedig a konvergenciaelméleteket és a mérési módszereket ismerteti.

\section{A KKE mezőgazdasági teljesítményei}

A Szovjetunió felbomlása óta számos szerző végzett vizsgálatot a kelet-közép-európai országok mezőgazdasági és élelmiszeripari szektorainak versenyképességéről. Az irodalmak egy része az EU-csatlakozás várható hatásait elemezte. A 2000-es évek elején számos könyv jelent meg a várható hatások számszerüsítéséröl (TangermannBanse [2000], Hartell-Swinnen [2000]). Ugyanebben az időszakban több cikk is vizsgálta a kérdést. Bach és szerzőtársai [2008] például a Közös Agrárpolitika bevezetésének agrárgazdasági hatásait vizsgálta, és megállapította, hogy a régióban várhatóan megnő majd a mezőgazdasági termelés és a szektorból származó jólét is. Bchir és szerzőtársai [2003] ugyanakkor rámutatott, hogy az EU-csatlakozás komoly mezőgazdasági ármozgásokat és valutaárfolyam-eltéréseket is eredményezhet, valamint a külkereskedelem szerkezete is nagymértékben átalakulhat a határok és a kereskedelemkorlátozó intézkedések eltörlésének hatására.

A téma szakirodalmának másik része az EU-csatlakozás valós hatásait vizsgálta, melyekről jó áttekintést ad Jámbor és szerzőtársai [2016] cikke. A legfrissebb

\footnotetext{
${ }^{1}$ Bulgária (2007), Csehország (2004), Észtország (2004), Lengyelország (2004), Lettország (2004), Litvánia (2004), Magyarország (2004), Románia (2007), Szlovákia (2004), Szlovénia (2004), Horvátország (2013).
} 
cikkek közül kiemelendő Baráth-Fertő [2017] munkája, amely az európai mezőgazdaság termelékenységének mintáit vizsgálva talált némi konvergenciát. ZahorskyPokrivcak [2017] ugyanakkor a régió mezőgazdaságának hatékonyságát a teljes tényezőtermelékenység módszerével vizsgálva kimutatta, hogy az inputokat a legtöbb országban nem hatékony módon használják fel, így a konvergencia az EU15 szintjéhez képest továbbra is elmarad.

A cikkek egy része továbbá agrárpolitikai/politikai gazdaságtani szempontból vizsgálta a régió mezőgazdaságának teljesítményét. Gorton és szerzőtársai [2009] például a Közös Agrárpolitika alkalmazhatóságát vizsgálta a kelet-közép-európai régióban, és megállapításai szerint a Közös Agrárpolitika nem alkalmas a régió speciális problémáinak a kezelésére. Csáki-Jámbor [2013] hasonló következtetésre jutott, ahogyan Jámbor és szerzötársai [2016] is, amikor az EU-csatlakozás ötödik és tizedik évfordulója kapcsán elemezték a mezőgazdasági tanulságokat. Utóbbi cikk eredményei szerint Lengyelország és a balti államok számítanak az EU-csatlakozás egyértelmü nyerteseinek a mezőgazdaságban, míg Románia és Bulgária használta a legkevésbé ki a közös piac kínálta lehetőségeket a szektorban. Továbbá a hozzáadott értékre és a versenyképességre koncentráló agrárpolitika és agrárstratégia egyértelmüen pozitív hatással volt az agrárteljesítményekre, míg az alapanyagok termelésére és kereskedelmére összpontosító stratégia hosszú távon nem bizonyult hatékonynak.

\section{A FÁK mezögazdasági teljesítményei}

Ellentétben a kelet-közép-európai országokkal, a Független Államok Közösségének mezőgazdaságát elemző cikkek száma meglehetősen korlátozott. Csáki-Lerman [1997] az elsők között vizsgálta a földreformok hatásait és a földhasználat változásait az 1990-es években Kelet-Közép-Európában és a Független Államok Közösségében, és rámutatott, hogy az elért eredmények messze alulmúlták a várakozásokat mind mennyiségileg, mind minőségileg. Eredményeik szerint továbbá az agrárreformok a két térségben alapvetően mérsékeltek maradtak, főként a politikai és jogi bizonytalanság, a támogató környezet hiánya, a magas kockázat és a farmszerkezet átalakításának elmaradása miatt.

Lerman [2005] néhány évvel később hasonló következtetésekre jut, amikor a FÁK országait „vonakodó reformereknek” hívja, míg a Kelet-Közép-Európa országait valódi reformokra képes és agrárszempontból jobb teljesítményt nyújtó térségnek tartja. Rozelle-Swinnen [2004] is osztja ezt a nézetet, hogy Kelet-Közép-Európa és a Független Államok Közösségének agrárteljesítményeiben rejlő különbségek alapvető oka a reformok megléte és azok végrehajtásának sebessége. Lerman [2009] hozzáteszi továbbá, hogy a FÁK mezőgazdaságáról rendelkezésre álló adatok - és így elemzéseik - hiánya sem könnyítette meg a reformokat. A Független Államok Közösségének mezőgazdaságát vizsgáló irodalmak egy része egy-egy intézmény munkájához kötődik. A németországi székhelyü IAMO (Leibniz Institute of Agricultural Development in Transition Economies) intézet például leginkább egyes országok kiválasztott szektorának teljesítményeit elemzi mélyebben, ám ezen munkák 
részletes bemutatása messze vinne e cikk céljától (részletesebben lásd például Petrick [2014], Petrick-Djanibekov [2016] vagy Mogilevskii és szerzőtársai [2017] munkáit). A FAO Budapesti Irodájának munkái is ebbe a körbe tartoznak (például Lerman és szerzőtársai [2016] vagy Lerman-Sedik [2017] munkái).

\section{A konvergenciaelmélet és alkalmazhatósága}

A közgazdaságtanban a konvergencia fogalmát sokféleképpen lehet értelmezni és mérni. Szótári definíció szerint a fogalom „a konvergálás folyamatára utal, különösképpen az egység vagy egyezőség irányába hatóan” (de Jong [2018] 12. o.). A közgazdaságtanban a konvergenciával kapcsolatban általában a Solow-modellre gondolunk, amely szerint a szegényebb régiók gyorsabban nőnek, mint a gazdagabbak, és emiatt az elmélet szerint előbb-utóbb az egyes régiók fejlettsége kiegyenlítődik. Ezt a klaszszikus nézetet kérdőjelezte meg többek között az ezredforduló környékén Fujita és szerzőtársai [1999], kidolgozva ezzel egy új gazdaságföldrajzi elméletet, amely alapvetően központok és agglomerációk növekedéséről beszél.

Islam [2003] szerint a közgazdászok a következő dimenziókban értelmezik a konvergenciát: gazdaságon belül vagy gazdaságok között; növekedés vagy jövedelmi szint alapján; $\sigma$-vagy $\beta$-konvergencia szerint; abszolút vagy relatív értelemben; globálisan vagy lokálisan; jövedelem vagy termelékenység alapján; determinisztikus vagy sztochasztikus értelemben. A fenti elméletekről és nézőpontokról részletes áttekintést ad de Jong [2018] munkája.

A konvergencia kifejezést közgazdasági értelemben talán leggyakrabban az európai integráció kapcsán szokták használni. Ebben a keretben a konvergencia növekvö kohéziót jelent. A divergenciával vagy status quóval ellentétben ugyanis a konvergencia kiegyensúlyozottabb növekedést tesz lehetővé, amely mérhető is. A konvergencia az európai integráció egyik alapköve, hiszen az Európai Unió gazdasági, társadalmi és környezeti szempontból rendkívül sokszínü országok közössége, ahol a meglévő különbségek kiegyenlítése mint cél mindig jelen volt. Ezt tükrözi a maastrichti szerződés második cikkelye is, amely a gazdasági teljesítmények konvergenciáját célként jelöli meg. Mivel a konvergencia elérése nem egy véletlen folyamat eredménye, a döntéshozók az Európai Unióban létrehozták a strukturális politikát és alapokat: az Európai Regionális és Fejlesztési Alapot, a Kohéziós Alapot, az Európai Mezőgazdasági Orientációs és Garancia Alapot (azóta Európai Mezőgazdasági Garancia Alap és Európai Mezőgazdasági Vidékfejlesztési Alap), valamint az Európai Tengerügyi és Halászati Alapot és az előcsatlakozási alapokat.

Ami a konvergenciaelméletek alkalmazását illeti a mezőgazdaságban, számos módszer áll rendelkezésre. De Jong [2018] csoportosítása alapján a mezőgazdasági alkalmazásokban léteznek ár-, termelékenység- és jövedelemalapú módszerek.

Ami az árak konvergenciáját illeti, a legtöbb cikk az ártranszmisszió témájában született, azt elemezve, hogy a mezőgazdasági és élelmiszerárak változásai milyen mértékben és gyorsasággal jutnak el a végső fogyasztóhoz. Az elért eredmények nagymértékben függnek attól, hogy milyen szektort, milyen módszerrel és milyen 
sürüségű adatokkal vizsgálnak. Ugyanakkor világos, hogy a mezőgazdasági piacokon megjelenő ártranszmisszió általában tökéletlen, vagyis a termelői szinten megjelenő árváltozások nem teljes mértékben jutnak el a fogyasztókhoz (von Cramon-Taubadel és szerzötársai [2006]). Bakucs és szerzőtársai [2014] egy metaanalízissel vizsgálta a témában megjelent meghatározó cikkeket, és arra jutott, hogy az aszimmetrikus ártranszmisszió előfordulása gyakoribb olyan szektorokban, ahol a termelők egymástól jobban elkülönülnek, ahol a politikai érdekek erősebben megjelennek, és ahol a kiskereskedők koncentráltan vannak jelen.

Ami a termelékenységalapú módszereket illeti, Timmer és szerzőtársai [2010] az európai és amerikai mezőgazdaság termelékenységkülönbségeit vizsgálták, és kimutatták, hogy az Európai Unió termelékenysége az Egyesült Államok vonatkozó értékének kevesebb mint fele volt. Nem találtak ugyanakkor az európai mezőgazdaság termelékenységében semmilyen konvergenciára utaló jelet 1980 és 2005 között. Matthews [2014] hasonló következtetésre jutott a kelet-közép-európai régió mezőgazdaságának termelékenységét vizsgálva, amikor kimutatta, hogy 2002 és 2011 között a régió termelékenysége szignifikánsan alacsonyabb volt az EU15 vonatkozó értékeinél - sőt a különbség a vizsgált időszakban még nőtt is. Cechura és szerzőtársai [2014] az európai tejszektorban megjelenő termelékenységkülönbségeket vizsgálta, és a meglévő különbségek mellett felhívta a figyelmet, hogy a rosszabbul teljesítő gazdaságok nem mutatják a felzárkózás jeleit a jobban teljesítőkhöz. Ennek ellenkezőjét találta Baráth-Fertő [2017] az európai mezőgazdaság termelékenységét vizsgálva: a szerzők szerint kimutatható az Európai Unió mezőgazdaságának termelékenységében egyfajta konvergencia.

Végül, de nem utolsósorban a jövedelemalapú konvergenciavizsgálat a nemzetközi mezőgazdasági szakirodalomban talán az egyik leginkább kutatott terület, mivel számos fejlődés-gazdaságtani és szociális vonatkozása van. Az ilyen jellegü vizsgálatok leginkább az egy före jutó GDP-ben vagy az egy före jutó GNI-ben, illetve a termelöi jövedelmekben megjelenő konvergenciát keresik. Brasili és szerzötársai [2006] például találtak konvergenciát a mezőgazdaságból származó jövedelmekben az Európai Unió és az Egyesült Államok termelöit vizsgálva. Hansen-Teuber [2011] kutatása is ebbe a körbe tartozik - a szerzőpáros a Közös Agrárpolitika hatását vizsgálta a regionális konvergenciára, és kimutatta, hogy a jövedelemkülönbségek alapvetően nőttek, ugyanakkor az egyes szektorokból származó jövedelemkülönbségek enyhültek.

\section{Módszertan}

A cikk a felsorolt lehetőségek közül termelékenységalapon méri a konvergenciát. Ehhez parciális termelékenységmutatókat (föld- és munkaalapon) használ a számítások elvégzésére. Bár számos más módszer áll rendelkezésre a termelékenység mérésére a mezőgazdaságban, ${ }^{2}$ e módszerek rendkívül sok adatot igényelnek. A választott

\footnotetext{
${ }^{2}$ Teljes tényezőtermelékenység (total factor productivity, TFP), burkológörbe-elemzés (data envelopment analysis, DEA), sztochasztikus határelemzés (stochastic frontier analysis, SFA).
} 
módszer mellett szól továbbá, hogy a cikk a bevezetésben leírtaknak megfelelően inkább egy holisztikus megközelítést alkalmaz, és nem a „technikai” elemzések számát szeretné bővíteni. További érv, hogy a hagyományos módszerek a két régióban megjelenő gazdaságok rendkívül nagy mértékű strukturális diverzitása miatt nehezen lennének a mintára alkalmazhatók.

Többféle lehetőség létezik az országok között megjelenő konvergencia tesztelésére is. Monfort [2008] kiváló áttekintést ad a rendelkezésre álló módszerekről, amelyeket az 1. táblázat foglal össze.

\section{1. táblázat}

A konvergencia mérésére alkalmas módszerek jellemzői

\begin{tabular}{llcc}
\hline & Módszer & Vizuális/kvantitatív & Terjedelem \\
\hline Béta-konvergencia & Béta-koefficiens & $\mathrm{K}$ & $0-\infty$ \\
\hline Szigma- & Szórás & $\mathrm{K}$ & $0-1$ \\
konvergencia & Gini-index & $\mathrm{K}$ & $0-1$ \\
& Atkinson-index & $\mathrm{K}$ & $0-1$ \\
& Theil-index & $\mathrm{K}$ & $0-\infty$ \\
& Átlagos logaritmikus eltérés (MLD) & $\mathrm{K}$ & $0-\infty$ \\
\hline Eloszlásvizsgálat & Kernel-sűrüség becslése & $\mathrm{V}$ & - \\
& Kumulált gyakoriság & $\mathrm{V}$ & - \\
& Salter-térképek & $\mathrm{V}$ & - \\
\hline & Markov-valószínűségelemzés & $\mathrm{K}$ & - \\
\hline
\end{tabular}

Forrás: Monfort [2008] 20. o.

A cikk céljához és a választott közelítésmódhoz a leginkább a Kernel-féle sürüségábra alkalmazása illik, mivel arra vagyunk kíváncsiak, hogy mennyire aszimmetrikus a minta eloszlása. Ez a módszer továbbá jól alkalmazható arra is, hogy kimutassuk, időben vannak-e szignifikánsan eltérő termelékenységkülönbségek. Ezenfelül Markov-féle átmeneti valószínüségi mátrixot is használtunk, amely esetünkben jól alkalmazható a mintán belüli potenciális változások azonosítására. Más szavakkal, a Kernel-módszer a mintában megjelenő külső, míg a Markovmódszer a belső konvergencia azonosítására alkalmas. A módszerek további jellemzőiről jó áttekintést ad de Jong [2018].

A cikkben a STATA-szoftvercsomagot használtuk a számítások elvégzéséhez. A termelékenységi adatok forrása a FAO nemzetközi adatbázisa volt, ahol az 1997 és 2016 közötti évekre voltak elérhető adatok. A vizsgált kelet-közép-európai országok a következők: Bulgária, Csehország, Észtország, Lengyelország, Lettország, Litvánia, Magyarország, Románia, Szlovákia és Szlovénia. Nem szerepel a vizsgálatban a rendelkezésre álló adatok alacsony száma miatt Horvátország. A Független Államok Közösségének mintában szereplő országai a következők: Azerbajdzsán, Fehéroroszország, Kazahsztán, Kirgizisztán, Moldova, Oroszország, Örményország, 
Tádzsikisztán, Ukrajna és Üzbegisztán. Grúziára és Türkmenisztánra nem voltak elérhetők a megfelelő adatok.

Annak érdekében, hogy a termelékenységben megjelenő változásokat jobban tudjuk szemléltetni, a mintát három részre osztottuk: magas termelékenységgel rendelkező országokra (amelyek termelékenysége a mezőgazdaságban legalább 25 százalékkal meghaladja az EU15 átlagát), alacsony termelékenységủ országokra (amelyek termelékenysége a mezőgazdaságban nem éri el az EU15 átlagos értékének 75 százalékát) és átlagos termelékenységű országokra (a fenti két kategóriába nem tartozó országok).

\section{Mezőgazdasági teljesítmények a rendszerváltás után}

A kelet-közép-európai országok és a Független Államok Közösségének mezőgazdasági teljesítményeit a rendszerváltás után számos mutatóval lehet elemezni. Ezek közül az egyik legfontosabb a mezögazdasági hozzáadott érték, amely a Független Államok Közösségében a vizsgált időszakban alapvetően növekvő tendenciát mutatott (1. ábra).

\section{1. ábra}

Mezőgazdasági hozzáadott érték a Független Államok Közösségében, 1997-2016

(milliárd dollár)

\section{Milliárd dollár}

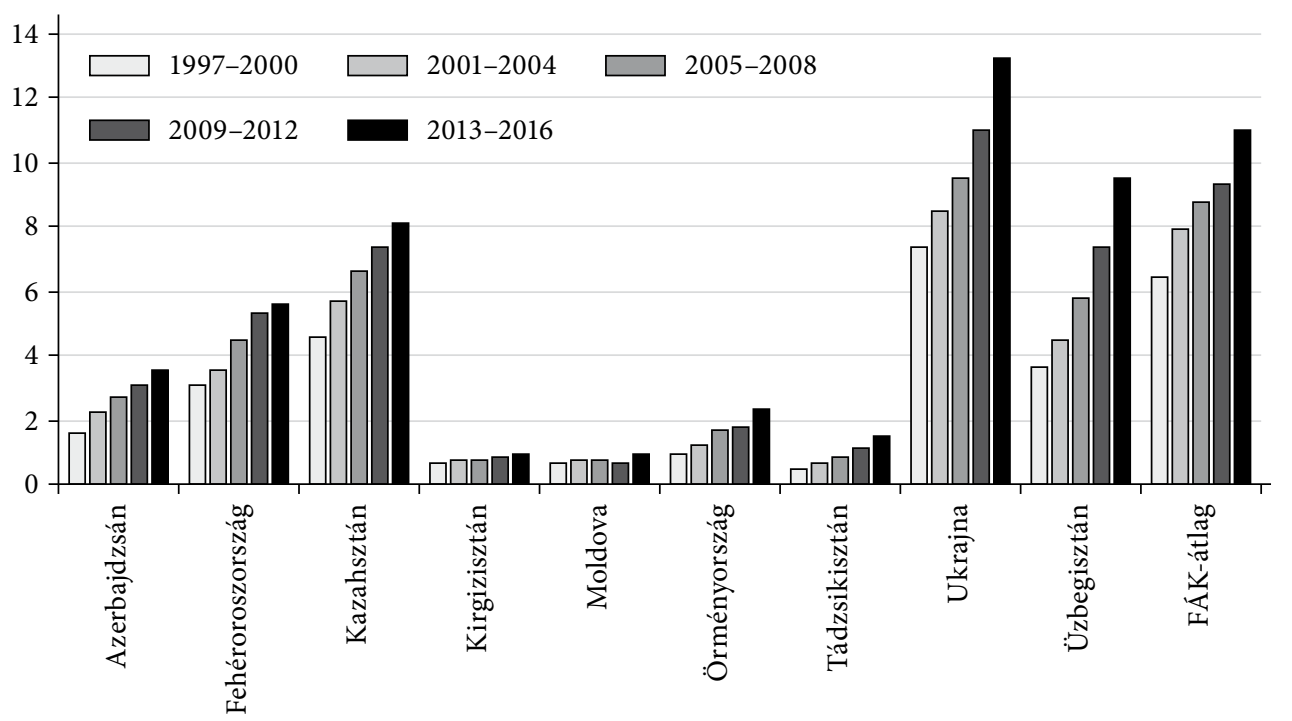

Megjegyzés: Oroszország vonatkozó értékei nagyságuk miatt nem szerepelnek az ábrán. Forrás: saját szerkesztés FAO-adatok (2018) alapján (http://www.fao.org/faostat/en).

A növekvő tendencia mögött ugyanakkor az egyes országok rendkívül eltérő teljesítményei figyelhetők meg. Abszolút értelemben Oroszország 62 milliárd dolláros mezőgazdasági hozzáadott értéke magasan meghaladta a régiós értékeket 
2013-2016-ban, Oroszországot Ukrajna követte a sorban 13 milliárd dollárral. A legkisebb mezőgazdasági hozzáadott értéke (1 milliárd dollár alatt) Kirgizisztánnak és Moldovának volt 2013-2016-ban. Relatív értelemben ugyanakkor Tádzsikisztán tudta a mezőgazdasági hozzáadott értékét a legnagyobb mértékben növelni 1997-2000 és 2013-2016 között (+235 százalék), míg Moldova teljesítménye volt a legkisebb ilyen értelemben (+32 százalék).

Ami a mezőgazdasági hozzáadott érték alakulását illeti a kelet-közép-európai régióban, a tendenciák alapvetően különböznek (2. ábra). Egyfelöl a mezőgazdasági hozzáadott érték a legmagasabb Lengyelországban és Romániában volt, rendre meghaladva a 12 milliárd és 10 milliárd dolláros értéket 2013-2016-ban, míg az észt és szlovén értékek voltak 1 milliárd dollár alatt. Másfelől a Független Államok Közösségénél tapasztalt tendenciákkal ellentétben a mezőgazdasági hozzáadott érték kevésbé nőtt a régió vizsgált országaiban 1997-2000 és 2013-2016 között. A legnagyobb növekedés Szlovákia (+127 százalék), Lettország (+65 százalék) és Észtország (+56 százalék) esetében volt megfigyelhető.

\section{2. ábra}

Mezőgazdasági hozzáadott érték a kelet-közép-európai országokban, 1997-2016 (milliárd dollár)

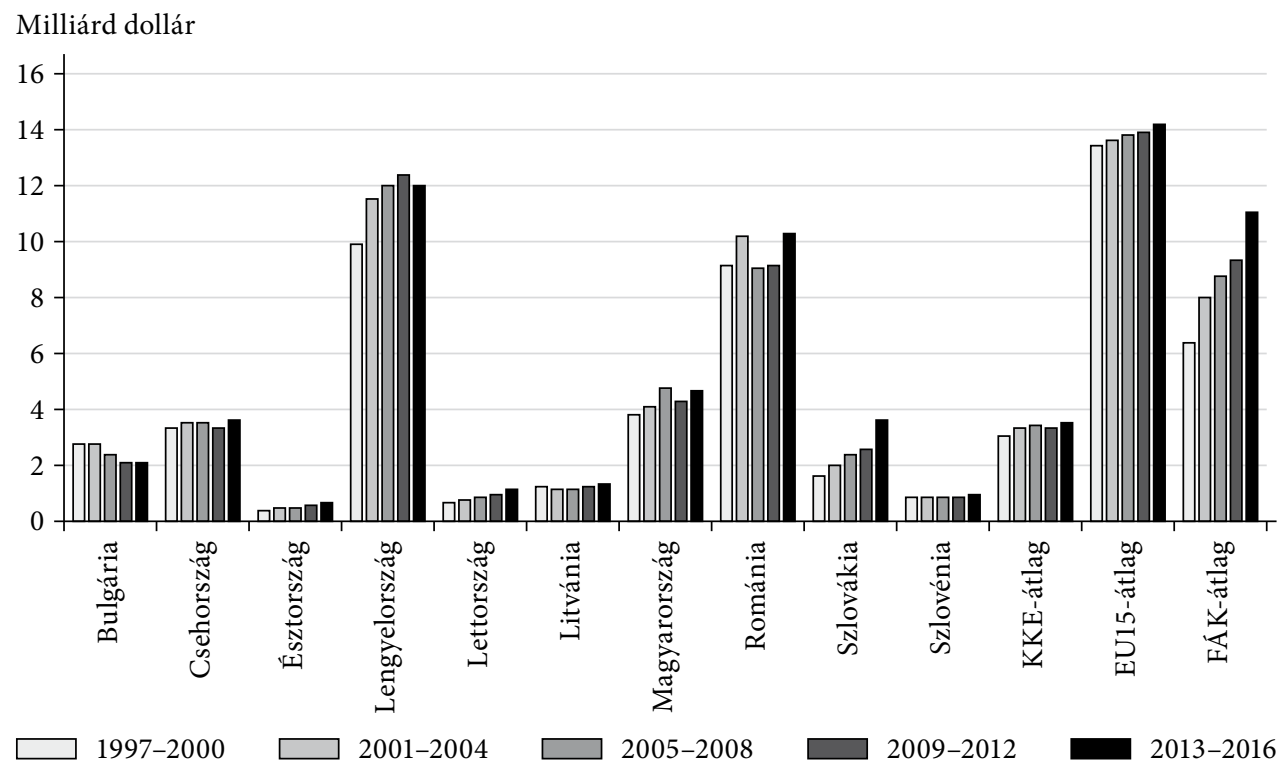

Forrás: saját szerkesztés FAO-adatok (2018) alapján (http://www.fao.org/faostat/en).

Érdemes továbbá megfigyelni, hogy amíg a mezőgazdasági hozzáadott érték átlagos növekedése a vizsgált időszakban 16 százalék volt a kelet-közép-európai régióban, addig ugyanez az érték 72 százalék volt a Független Államok Közösségében, ami már elörevetít egyfajta konvergenciát. Ugyanakkor az is látható a 2. ábrából, hogy továbbra is komoly különbség van az EU15 hozzáadott értéke és a két régió megfelelö értékei között. A kelet-közép-európai régió rosszabb teljesítménye 
részben azzal magyarázható, hogy az utóbbi két évtizedben egyre kevésbé intenzív mezőgazdasági termelés zajlik Kelet-Közép-Európában, részben pedig azzal, hogy az alacsony hozzáadott értékủ gabonatermelés több országban is erőteljesen jelen van a régióban.

$\mathrm{Az}$ agrárkereskedelem is komoly változásokon ment keresztül mindkét régióban a vizsgált időszakban. Ahogy a 3. ábrán látható, az agrárkereskedelmi deficit Oroszországban volt a legnagyobb (15 milliárd dollár) 2013-2016-ban, míg Ukrajna érte el a FÁK-országok közül a legnagyobb agrárkereskedelmi többletet (8 milliárd dollár) ugyanebben az időszakban. Ukrajna volt egyébként az egyetlen ország a Független Államok Közösségén belül, amely komoly agrárkereskedelmi többletet tudott felmutatni minden időszakban, ráadásul 1997-2000 és 2013-2016 között tizenkétszeresére növelte agrárkereskedelmi egyenlegét. A Független Államok Közösségének átlagos agrárkereskedelmi egyenlegét jelentős mértékben befolyásolta ugyanakkor az orosz import, amely a legnagyobb méreteket éppen a gazdasági válság utáni időszakban öltötte (2009-2012 időszakában).

\section{3. ábra}

Agrárkereskedelmi egyenleg a Független Államok Közösségében, 1997-2016 (milliárd dollár)

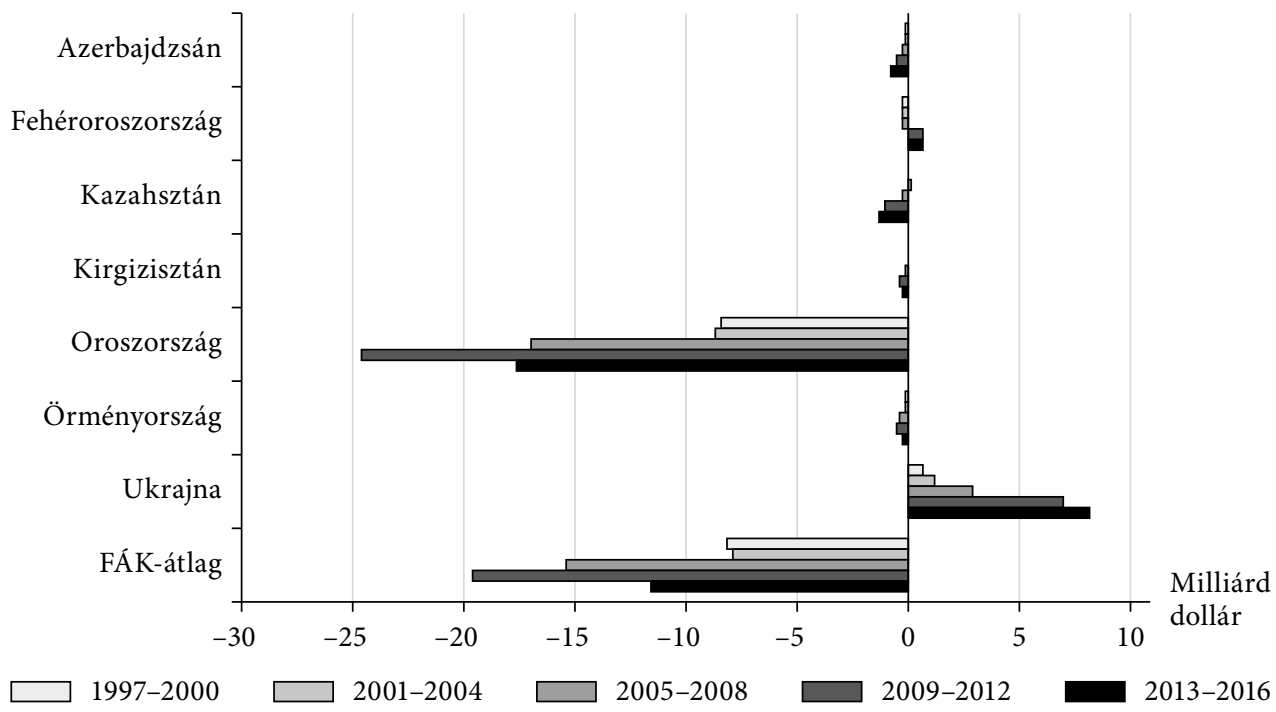

Forrás: saját szerkesztés FAO-adatok (2018) alapján (http://www.fao.org/faostat/en).

Az agrárkereskedelem egyenlege némileg más képet mutat Kelet-Közép-Európában (4. ábra). 2013-2016 között Lengyelországé volt a legnagyobb többlet (8,5 milliárd dollár), amelyet a magyar (3,9 milliárd dollár) és a bolgár (1,6 milliárd dollár) agrárkereskedelmi többlet követett. Érdemes megfigyelni, hogy Lengyelország 1997-2000-ben még nettó agrárimportőr ország volt. Az agrárkereskedelem egyenlegében a vizsgált időszakban a legnagyobb növekedést szintén Lengyelország érte el (több mint tízszeres növekedés), amelyet Litvánia (közel tízszeres növekedés) és Bulgária (+628 százalék) követett. Az EU15 agrárkereskedelmi teljesítményét 
a kelet-közép-európai országok valamelyest követték, míg a FÁK államai messze elmaradtak attól. Ehhez nagyban hozzájárult, hogy a kelet-közép-európai országok döntően az EU15-tel cserélnek mezőgazdasági és élelmiszeripari termékeket, ami az európai integráció erős hatására utal (Csáki-Jámbor [2016]).

\section{4. ábra}

Agrárkereskedelmi egyenleg a kelet-közép-európai országokban, 1997-2016 (milliárd dollár)

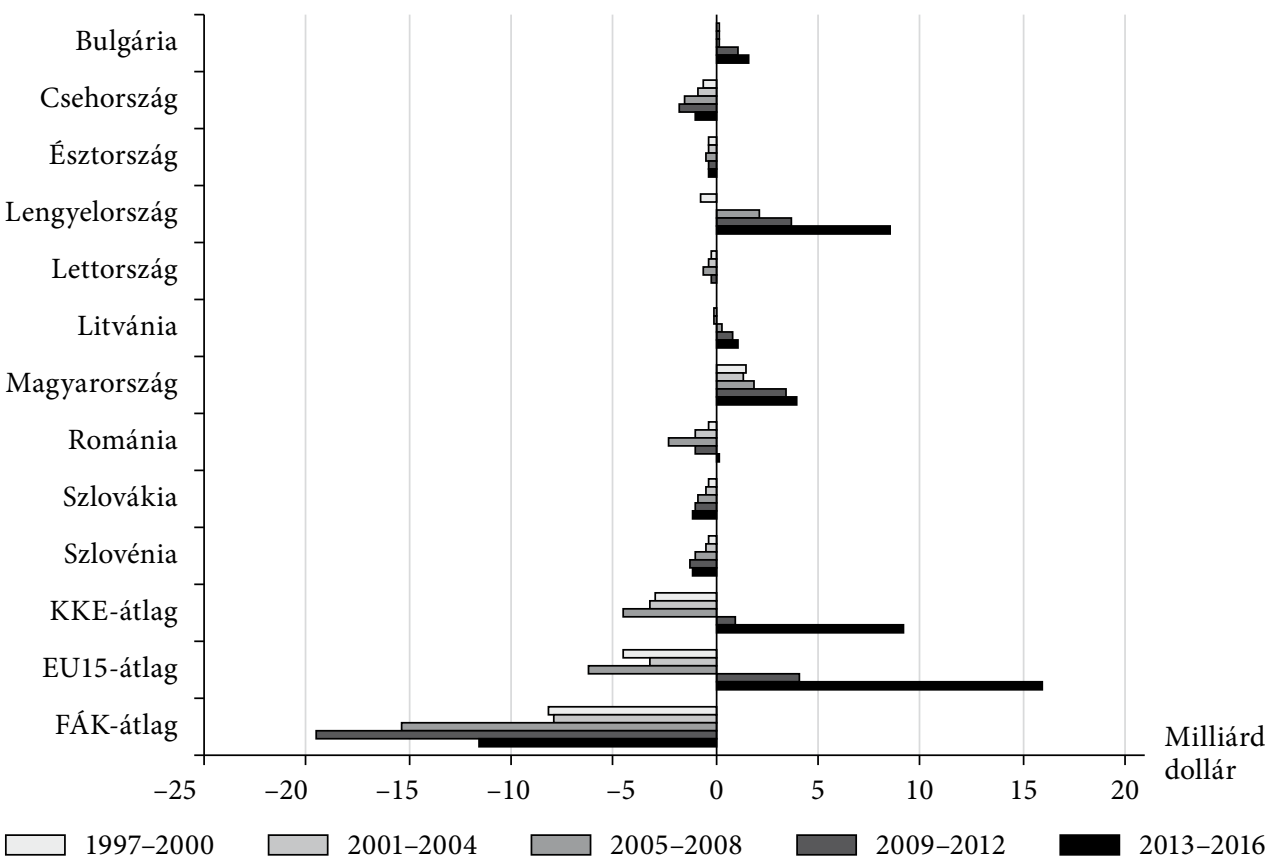

Forrás: saját szerkesztés FAO-adatok (2018) alapján (http://www.fao.org/faostat/en).

\section{Mérsékelt konvergencia a termelékenységben}

Az egyes régiók mezőgazdaságának termelékenysége alapvetően más képet mutat, mint a fenti naturális mutatók. A Független Államok Közösségében Örményország áll az élen területi termelékenység alapján, ami 2013-2016 átlagában 1400 dollár hektáronkénti kibocsátást jelentett, messze meghaladva ezzel a régiós átlagot (5. ábra). Ez a teljesítmény részben a magas hozzáadott értéket előállító zöldség- és gyümölcsszektor nagy súlyának volt köszönhetö. Ezenfelül Azerbajdzsán és Fehéroroszország is viszonylag jól teljesített ilyen téren - a FÁK országainak átlaga egyébként 200 dollár volt hektáronként 2013-2016-ban. Bár a Független Államok Közössége országainak többségében nőtt a területi termelékenység a mezőgazdaságban a vizsgált időszakban, ez a növekedés meglehetősen mérsékelt volt, ahogy látható is az 5. ábrán. 


\section{5. ábra}

Területi termelékenység a Független Államok Közösségének mezőgazdaságában, 1997-2016 (dollár/hektár)

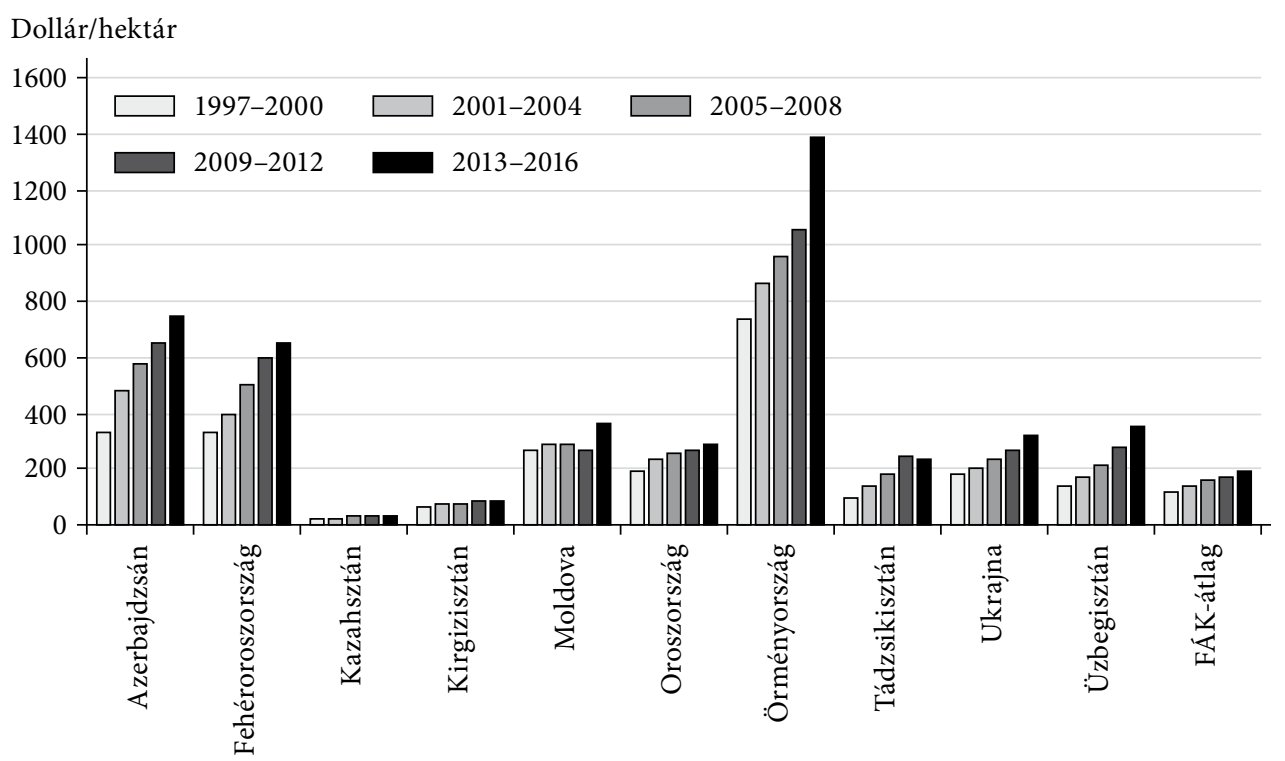

Forrás: saját szerkesztés FAO-adatok (2018) alapján (http://www.fao.org/faostat/en).

Hasonló képet mutatnak a kelet-közép-európai országok is mezőgazdasági területi termelékenység tekintetében (6. ábra). Bulgáriát és Szlovéniát kivéve minden ország képes volt növelni az egy hektárra jutó mezőgazdasági hozzáadott értékét 1997-2000 és 2013-2016 között, bár ez a növekedés a legtöbb esetben mérsékeltnek bizonyult (a szlovák adatokat megbízhatóságuk miatt érdemes óvatosan kezelni). Összességében a régió nagyon sokszínü ilyen tekintetben - a megfelelö szlovák és szlovén értékek az EU15 átlagos szintje körül mozognak, ugyanakkor a legtöbb ország komoly lemaradásban van a nyugat-európai termelékenységet tekintve. Ez a lemaradás a Független Államok Közössége esetében még nagyobb - összességében az EU15 és a kelet-közép-európai országok között négyszeres, míg az EU15 és a Független Államok Közössége között nyolcszoros különbség figyelhető meg. Ilyen szempontból a konvergencia korlátozottnak mondható.

Ami a mezőgazdasági munkatermelékenységet illeti, a leghatékonyabbak az örmény, fehérorosz és orosz termelök voltak - mindhárom ország esetében több mint 10000 dollárt bocsátott ki egy munkás a mezőgazdaságban átlagosan (7. ábra). A Független Államok Közösségében továbbá komoly növekedést lehetett tapasztalni a munkatermelékenységben a vizsgált időszakban. Moldova (+257 százalék), Fehéroroszország (+247 százalék), valamint Örményország és Ukrajna (mindketten +219 százalék) tudtak ilyen téren a leginkább növekedni 1997-2000 és 2013-2016 között, míg Kirgizisztán mutatta ezen a téren a legkisebb növekedést (+58 százalék). A Független Államok Közösségének átlagos növekedése is közel háromszoros volt a vizsgált időszakban. Az általános növekedés oka leginkább a mezőgazdasági 
6. ábra

Területi termelékenység a kelet-közép-európai országok mezőgazdaságában, 1997-2016 (dollár/hektár)

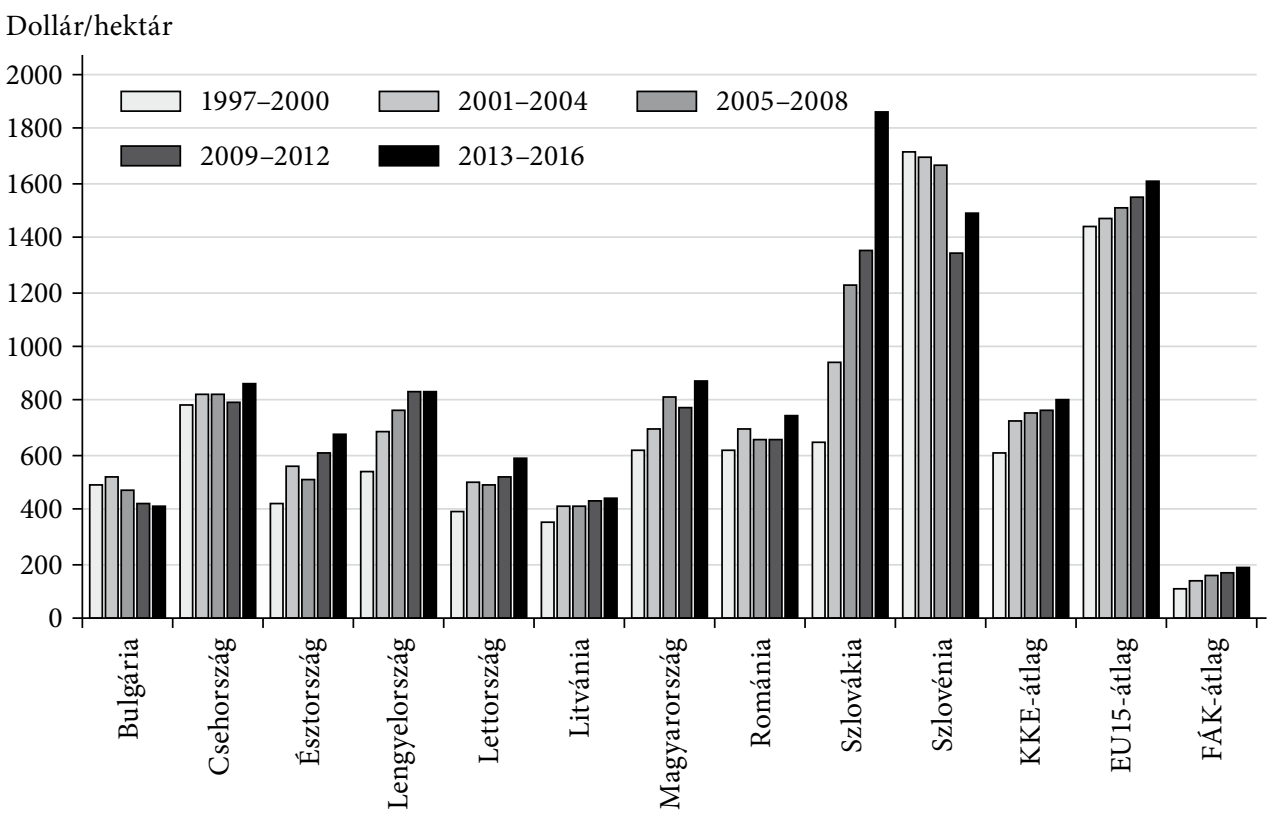

Forrás: saját szerkesztés FAO-adatok (2018) alapján (http://www.fao.org/faostat/en).

munkaerő csökkenő száma volt a régióban, amely a gazdasági fejlődéssel együtt járó általános jelenség. Ugyanakkor a munkatermelékenység növekedése a Független Államok Közösségében elterjedő modern mezőgazdasági technológiáknak is egyértelmüen a következménye.

A mezőgazdasági munkaerő termelékenysége a kelet-közép-európai országokban is nőtt 1997-2000 és 2013-2016 között (8. ábra). Ez volt az a terület, ahol talán a leginkább érzékelhető a konvergencia az EU15 szintjéhez. A legmagasabb növekedést ezen a téren Szlovákia (+217 százalék) és Románia (+214 százalék) tudta felmutatni, míg a legkisebb növekedés Csehországhoz tartozott (+72 százalék). Ugyanakkor látni kell, hogy a kelet-közép-európai országok jóval magasabb szintről kezdték növelni mezőgazdasági munkatermelékenységüket. A Független Államok Közössége és a kelet-közép-európai országok mezőgazdasági munkatermelékenységben meglévő különbsége még így is négyszeres volt 2013-2016-ban (míg a Független Államok Közössége és az EU15 között nyolcszoros különbség volt ezen a téren ugyanebben az időszakban). Ami a konvergenciát illeti, a kelet-közép-európai országok kezdtek felzárkózni a nyugat-európai munkatermelékenység szintjéhez, mivel 1997-2000-ben a régió munkatermelékenysége még csak 36 százaléka volt az EU15 megfelelö értékének, míg 2013-2016-ban ez az arány már 63 százalék volt.

Amennyiben a területi termelékenységben megjelenő konvergenciát a módszertani részben leírtaknak megfelelően Kernel-féle sürüségfüggvénnyel vizsgáljuk, arra 


\section{7. ábra}

Munkatermelékenység a Független Államok Közösségének mezőgazdaságában, 1997-2016 (ezer dollár/fö)

\section{Ezer dollár/fő}

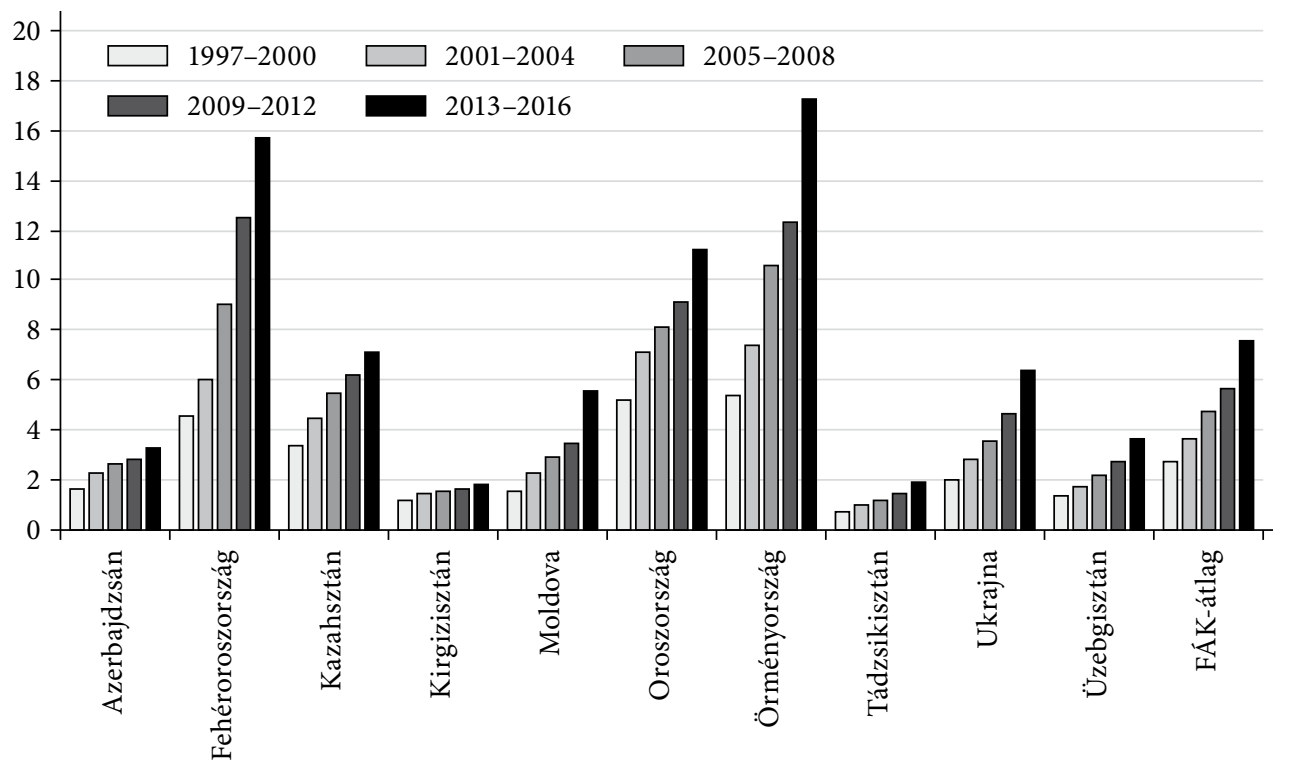

Forrás: saját szerkesztés FAO-adatok (2018) alapján (http://www.fao.org/faostat/en).

8. ábra

Munkatermelékenység a kelet-közép-európai országok mezőgazdaságában, 1997-2016 (ezer dollár/fö)

Ezer dollár/fő

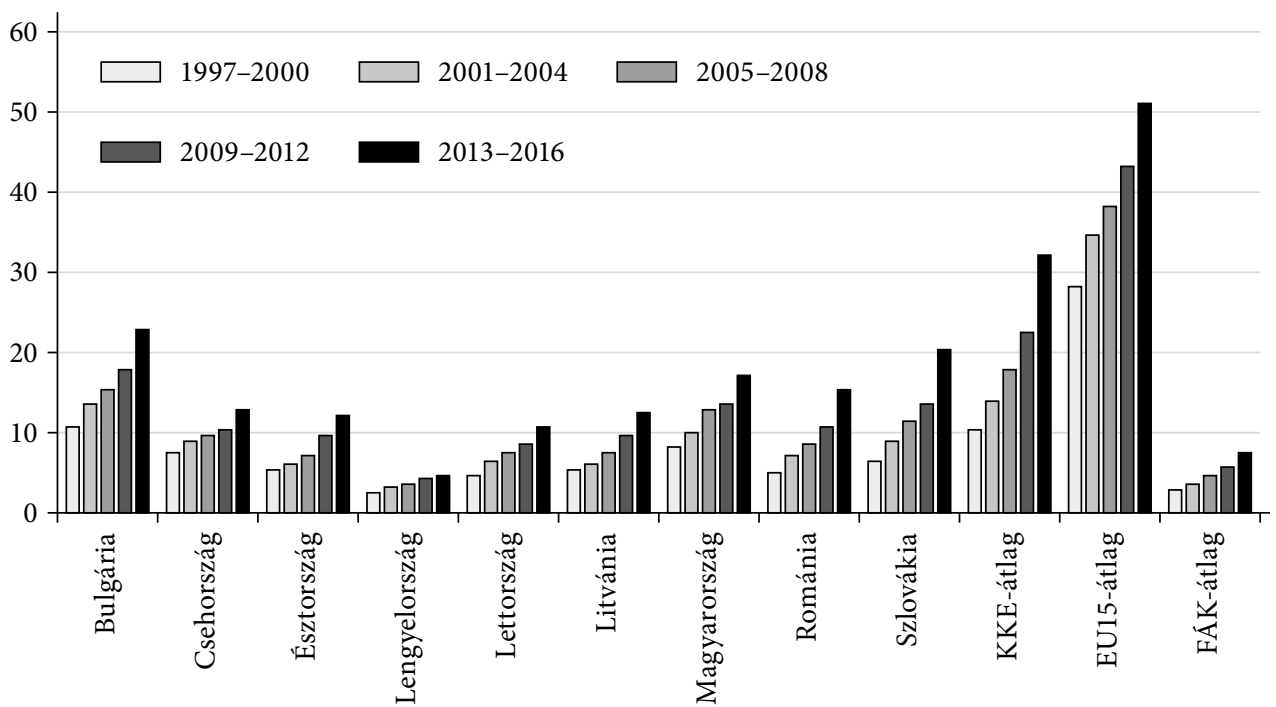

Forrás: saját szerkesztés FAO-adatok (2018) alapján (http://www.fao.org/faostat/en). 
jutunk, hogy nem látható ezen a téren semmilyen konvergenciára utaló jel. Ahogyan a 9. ábrán látszik, a minta eloszlása rendkívül hasonló, az 1000 euró/hektár körüli értéknél tapasztalható egy csúcsosodás, de ez időben nem változik. Más szavakkal, a mezőgazdaság területi termelékenységében meglévő különbségek mindkét vizsgált régió esetében stabilnak bizonyultak a vizsgált időszakban.

\section{9. ábra}

Kernel-féle sűrüségfüggvény a mezőgazdaság területi termelékenységére a mintában, 1997-2016

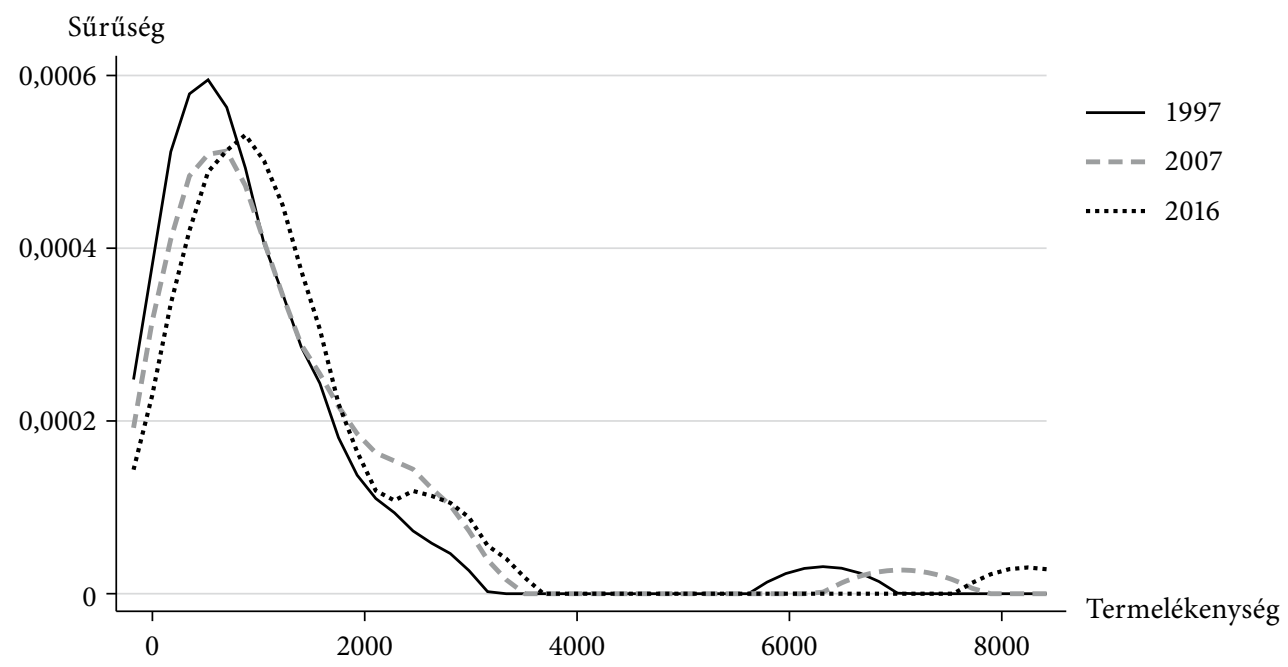

Forrás: saját szerkesztés FAO-adatok (2018) alapján (http://www.fao.org/faostat/en).

A Markov-féle átmeneti valószínűségi mátrixok alkalmazásával is hasonló eredményekre juthatunk. A FÁK-régió esetében minden vizsgált ország mezőgazdasági területi termelékenysége az EU15-átlag 75 százaléka alatt volt 1997-2000 között, és Örményország kivételével ott is maradt, Örményországnak 2013-2016-ra sikerült megközelítenie az EU15 átlagát. A minta eloszlásának stabilitása tehát arra utal (2. táblázat), hogy a legtöbb ország nem tudta érdemben csökkenteni a területi termelékenységében meglévő lemaradását.

\section{2. táblázat}

Átmeneti valószínűségi mátrix a Független Államok Közösségének mezőgazdasági területi termelékenységére vetítve (1997-2000-ről 2013-2016-ra)

\begin{tabular}{lrccc}
\hline Kezdeti eloszlás & & $<75$ százalék & $76-124$ százalék & $>125$ százalék \\
\hline 10 & $<75$ százalék & 0,9091 & 0,0909 & 0,0000 \\
0 & $76-124$ százalék & 0,0000 & 0,0000 & 0,0000 \\
0 & $>125$ százalék & 0,0000 & 0,0000 & 0,0000 \\
\hline
\end{tabular}

Forrás: saját szerkesztés FAO-adatok (2018) alapján (http://www.fao.org/faostat/en). 
Hasonló következtetésekre juthatunk a kelet-közép-európai országok esetében is (3. táblázat). Itt tízből nyolc ország számított alacsony területi termelékenységünek, és ebből hét az is maradt - az adatok szerint egyedül Szlovákia tudta ilyen téren növelni a teljesítményét, Szlovénia teljesítménye pedig az EU15 átlaga körül maradt végig a vizsgált időszakban.

\section{3. táblázat}

Átmeneti valószínűségi mátrix a kelet-közép-európai országok mezőgazdasági területi termelékenységére vetítve (1997-2000-ről 2013-2016-ra)

\begin{tabular}{lrccc}
\hline Kezdeti eloszlás & & $<75$ százalék & $76-124$ százalék & $>125$ százalék \\
\hline 9 & $<75$ százalék & 0,8181 & 0,0909 & 0,0000 \\
1 & $76-124$ százalék & 0,0000 & 0,0909 & 0,0000 \\
0 & $>125$ százalék & 0,0000 & 0,0000 & 0,0000 \\
\hline
\end{tabular}

Forrás: saját szerkesztés FAO-adatok (2018) alapján (http://www.fao.org/faostat/en).

A mezőgazdasági munkaerő termelékenységében még a fentinél is kevesebb konvergencia tapasztalható. A Kernel-féle sürüségfüggvény itt sem mutat konvergenciára utaló jeleket, akárcsak a területi termelékenység esetén (10. ábra).

10. ábra

Kernel-féle sürüségfüggvény a mezőgazdaság munkaerö-termelékenységére a mintában, 1997-2016

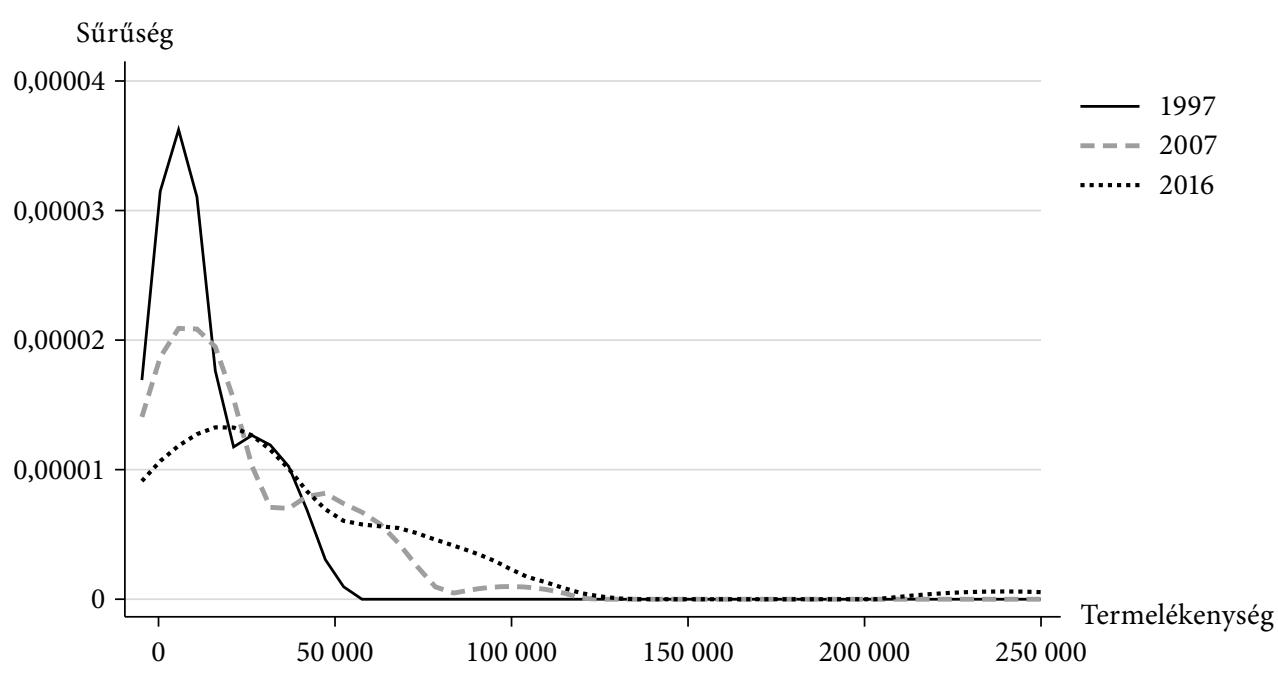

Forrás: saját szerkesztés FAO-adatok (2018) alapján (http://www.fao.org/faostat/en).

A Markov-féle átmeneti valószínűségi mátrixok is megerősítik a fenti megállapítást. Mindkét régió esetében a mezőgazdasági munkaerő termelékenysége nem érte el az EU15 átlagának 75 százalékát 1997-2000 között, és ott is maradt 2013-2016-ra. A vizsgált 20 évben egyetlen ország sem tudta növelni az alacsony 
munkaerő-termelékenységét, ami arra utal, hogy a kezdeti különbségek legjobb esetben is stabilizálódtak (4. és 5. táblázat).

\section{4. táblázat}

Átmeneti valószínűségi mátrix a Független Államok Közösségének mezőgazdasági munkaerő-termelékenységére vetítve (1997-2000-ről 2013-2016-ra)

\begin{tabular}{lrccc}
\hline Kezdeti eloszlás & & $<75$ százalék & $76-124$ százalék & $>125$ százalék \\
\hline 10 & $<75$ százalék & 1,0000 & 0,0000 & 0,0000 \\
0 & $76-124$ százalék & 0,0000 & 0,0000 & 0,0000 \\
0 & $>125$ százalék & 0,0000 & 0,0000 & 0,0000 \\
\hline
\end{tabular}

Forrás: saját szerkesztés FAO-adatok (2018) alapján (http://www.fao.org/faostat/en).

\section{5. táblázat}

Átmeneti valószínűségi mátrix a kelet-közép-európai országok mezőgazdasági munkaerőtermelékenységére vetítve (1997-2000-ről 2013-2016-ra)

\begin{tabular}{lrccc}
\hline Kezdeti eloszlás & & $<75 \%$ & $76-124 \%$ & $>125 \%$ \\
\hline 10 & $<75$ százalék & 1,0000 & 0,0000 & 0,0000 \\
0 & $76-124$ százalék & 0,0000 & 0,0000 & 0,0000 \\
0 & $>125$ százalék & 0,0000 & 0,0000 & 0,0000 \\
\hline
\end{tabular}

Forrás: saját szerkesztés FAO-adatok (2018) alapján (http://www.fao.org/faostat/en).

\section{A mérsékelt konvergencia mögött álló lehetséges okok}

Az országok különböző teljesítményei és az összességében mérsékelt konvergencia mögött számos lehetséges ok húzódik meg. Először is mindkét régió komoly nehézségekkel nézett szembe a piacgazdaságra való átállás folyamán. Ahogyan Csáki [2005] megállapította, az átállás és a vele járó privatizáció és szerkezeti átalakítás olyan sokkot jelentettek mindkét régióban, amelyet nem biztos, hogy a nyugat-európai országok bármelyike is átvészelt volna.

Továbbá a gazdasági és politikai változásokat komoly intézményi változások is kísérték, amelyek nem minden esetben voltak jól átgondoltak és szervezettek. A hosszú távú agrárstratégiák hiánya és a rövid távú mezőgazdasági érdekek alapvetően meghatározták az intézményi kereteket is, aminek következtében sokszor még a jó elgondolások is alacsony hatékonysággal valósultak meg (Csáki-Lerman [1997]).

Az EU-csatlakozás Kelet-Közép-Európában szintén fontos szerepet játszott a mezőgazdasági szektor teljesítményében. A kelet-közép-európai országok az EU-csatlakozással a közös piac részévé váltak, ami sok lehetőséget, de ugyanakkor komoly kihívásokat is tartogatott. Azok az országok, amelyek a versenyképesség fejlesztésére és a termelékenység növelésére koncentráltak, hosszabb távon sikeresebbnek bizonyultak, mint a rövid távú célokat kitűző társaik (Swinnen-Rozelle [2006]). 
Ami a konkrét teljesítményeket illeti, Jámbor és szerzőtársai [2016] számításai szerint Lengyelország és a balti államok voltak a csatlakozás egyértelmủ nyertesei az agráriumban, míg Románia és Bulgária használták ki a legkevésbé a közös piacban rejlő előnyöket. Eredményeik szerint továbbá a magasabb hozzáadott értékű termékekre súlyt helyező stratégia sikeresebbnek bizonyult, mint az alapanyag-termelés ösztönzése. Ugyanakkor komoly probléma a konvergencia mérsékelt szintje a keletközép-európai országok esetében, ha figyelembe vesszük, mekkora összegek érkeztek az ágazatba az EU-csatlakozás után ebben a régióban.

Ami a Független Államok Közösségét illeti, az elhúzódó és többségében átgondolatlan reformok nem segítették a szektor teljesítményének javulását, ahogyan az sem, hogy nem volt egyfajta külső kényszer ezek bevezetésére (ahogyan a kelet-középeurópai régióban volt az EU-csatlakozás miatt). Az eredmények szerint Oroszország 2012 óta alkalmazott protekcionista agrárpolitikája sem hozta meg a várt termelékenységnövekedést. Ugyan az embargó vezérelte politikáknak már megvannak a struktúraátalakítást mutató első jelei, azok hosszú távú hatása kétséges. Nem segítette továbbá a szektor átalakulását a helyi agrárgazdasági kutatási irányok nemzetközi szinten mérsékelt jellege sem.

Összességében tehát elmondható, hogy a Független Államok Közössége és a keletközép-európai országok mezőgazdasági hatékonyság tekintetében mutatnak némi konvergenciát az EU15 átlagához, ugyanakkor ennek mértéke mérsékelt. A keletközép-európai országok teljesítménye mindenesetre meggyőzőbb ilyen téren, mint a Független Államok Közösségéé, s ez leginkább a szükséges reformok végrehajtásának hatékonyságán és gyorsaságán múlott, ahogyan Lerman [2005] megállapította. Tanulmányunk következtetése ilyen szempontból hasonló ahhoz, amire közel 20 éve Csáki-Lerman [1997] jutott: azok az országok, amelyek kellően bátrak és gyorsak a reformok végrehajtásában, hosszú távon sikeresebbek, mint a rövid távú előnyökre koncentráló szomszédaik.

Ebben a tanulmányban a Független Államok Közössége és a kelet-közép-európai országok mezőgazdaságában mutatkozó konvergenciát vizsgáltuk az EU15 átlagos teljesítményeihez képest. A következtetések megalapozásához Kernel-féle sűrűségfüggvényeket és Markov-féle átmeneti valószínűségi mátrixokat alkalmaztunk a területi és munkaerö-termelékenységre a mezőgazdaságban 1997 és 2016 között. Az eredményeink szerint mindkét vizsgált régió és tényező esetében továbbra is komoly a lemaradás az EU15-értékektöl, és mérsékelt a konvergenciaszint is: a legtöbb ország továbbra sem éri el a megfelelő EU15-teljesítmények 75 százalékát sem. Továbbá azonosítottuk a mérsékelt konvergencia mögött álló okokat, amelyek közül talán a leginkább meghatározók a piacgazdaságra való átállás folyamata, az EU-csatlakozást megelöző és követő agrárpolitikák, valamint a Független Államok Közössége esetében a szükséges reformok lassú és átgondolatlan jellege volt. 


\section{Hivatkozások}

Bach, C. F.-Frandsen, S. E.-Jensen, H. G. [2008]: Agricultural and Economy-Wide Effects of European Enlargement: Modelling the Common Agricultural Policy. Journal of Agricultural Economics, Vol. 51. No. 2. 162-180. o. https://doi.org/10.1111/j.1477-9552.2000.tb01221.x.

Bakucs Zoltán-Falkowski, J.-Fertő Imre [2014]: Does Market Structure Influence Price Transmission in the Agro-food Sector? A Meta-analysis Perspective. Journal of Agricultural Economics, Vol. 65. No. 1. 1-25. o. https://onlinelibrary.wiley.com/doi/ abs/10.1111/1477-9552.12042.

Baráth Lajos-Fertő Imre [2017]: Productivity and Convergence in European Agriculture. Journal of Agricultural Economics, Vol. 68. No. 1.228-248. o. https://doi.org/10.1111/14779552.12157.

BChir, H.-Fontagne, L.-ZAnghieri, P. [2003]: The Impact of EU Enlargement on Member States: A CGE Approach. CEPII Working Paper, No. 10.

Brasili, C.-Fanfani, R.-Gutierrez, L. [2006]: Convergence in the Agricultural Incomes: A Comparison between the US and EU. Contributed paper prepared for presentation at the International Association of Agricultural Economists Conference, Gold Coast, Australia, augusztus 12-18. http://ageconsearch.umn.edu/bitstream/25363/1/cp060733.pdf.

Cechura, L.-Grau, A.-Hockmann, H.-Levkovych, I.-Kroupova, Z. [2014]: Catching up or falling behind in Eastern European agriculture: The case of milk production. 142nd EAAE Seminar Growing Success? Agriculture and rural development in an enlarged EU. Corvinus University of Budapest, Budapest, május 29-30.

Csáki Csaba [2005]: Agricultural reforms in Central and Eastern Europe and the former Soviet Union Status and perspectives. Agricultural Economics, Vol. 22. No. 1. 37-51. o. https://doi.org/10.1016/S0169-5150(99)00039-0.

Csáki CsABA-JÁmbor Attila [2013]: The impact of EU accession: Lessons from the agriculture of the new member states. Post-Communist Economies, Vol. 25. No. 3. 325-342. o. https://doi.org/10.1080/14631377.2013.813139.

Csáki Csaba-Jámbor Attila [2016]: Ten Years of EU Membership: How Agricultural Performance Differs in the New Member States. EuroChoices, Vol. 15. No. 2. 35-41. o. https:// doi.org/10.1111/1746-692X.12107.

CsÁKI CSABA-LERMAN, Z. [1997]: Land reform and farm restructuring in East Central Europe and CIS in the 1990s: Expectations and achievements after the first five years. European Review of Agricultural Economics, Vol. 24. No. 3-4. 428-452. o. https://doi.org/10.1093/erae/24.3-4.428.

DE Jong, W. [2018]: Structural convergence between the dairy sectors of the EU-27 Member States. MSc Thesis Agricultural Economics and Rural Policy. Wageningen University, Wageningen, http://edepot.wur.nl/442832.

Fujita, M.-Krugman, P. R.-Venables, A. J. [1999]: The spatial economy: Cities, regions and international trade. MIT Press, Cambridge, MA.

Gorton, M.-Hubbard, C.-Hubbard, L. [2009]: The Folly of EU Policy Transfer: Why the CAP does not fit Central and Eastern Europe. Regional Studies, Vol. 43. No. 10. 1305-1317. o. https://doi.org/10.1080/00343400802508802.

Hansen, H.-Teuber, R. [2011]: Assessing the impacts of EU's common agricultural policy on regional convergence: Sub-national evidence from Germany. Applied Economics, Vol. 43. No. 26. 3755-3765. o. https://doi.org/10.1080/00036841003724395.

Hartell, J.-Swinnen, J. F. M. (szerk.) [2000]: Agriculture and East-West European Integration. Ashgate, Aldershot. 
IsLAm, N. [2003]: What have we learnt from the convergence debate? Journal of Economic Surveys, Vol. 17. No. 3. 309-362. o. https://doi.org/10.1111/1467-6419.00197.

Jámbor Attila-Somai Miklós-Kovács Sándor [2016]: 10 Years of EU Membership: Diverging Performances in New Member States Agriculture. Ekonomicky Casopis, Vol. 64. No. 5. 458-476. o.

Lerman, Z. [2005]: Agriculture in transition economies: From common heritage to divergence. Agricultural Economics, Vol. 26. No. 2. 95-114. o. https://doi.org/10.1016/S01695150(00)00107-9.

Lerman, Z. [2009]: Land Reform, Farm Structure, and Agricultural Performance in CIS Countries. China Economic Review, Vol. 20. No. 2. 316-326. o. https://doi.org/10.1016/j. chieco.2008.10.007.

Lerman, Z.-SEDiK, D. [2017]: Cooperatives in Kyrgyzstan: Findings from a Survey of Cooperatives and Users. Megjelent: Hendrikse, G.-Cliquet, G.-Ehrmann, T.-Windsperger, J. (szerk): Management and Governance of Networks: Contributions to Management Science. Springer, Cham.

Lerman, Z.-Sedik, D.-Yusupov, Y.-Stanchin, I.-KaZakevich, I. [2016]: Wheat production and regional food security in CIS: The case of Belarus, Turkmenistan, and Uzbekistan. FAO Regional Office for Europe and Central Asia. Policy Studies on Rural Transition, No. 1.

Matthews, A. [2014]: What is happening to EU agricultural productivity growth? CAP Reform blog, május 4. http://capreform.eu/what-is-happening-to-eu-agriculturalproductivity-growth.

Mogilevskit, R.-Abdrazakova, N.-Bolotbekova, A.-Chalbasova, S.-Dzhumaeva, S.Tilekeyev, K. [2017]: The outcomes of 25 years of agricultural reforms in Kyrgyzstan. IAMO Discussion Paper, No. 162. IAMO, Halle (Saale).

Monfort, P. [2008]: Convergence of EU regions: Measures and evolution. European Commission, Regional Policy, Brüsszel, http://ec.europa.eu/regional_policy/sources/docgener/ work/200801_convergence.pdf.

Petrick, M. [2014]: Modernising Russia’s cattle and dairy sectors under WTO conditions: Insights from East Germany. IAMO Discussion Paper, No. 150. IAMO, Halle (Saale).

Petrick, M.-Djanibekov, N. [2016]: Obstacles to crop diversification and cotton harvest mechanisation: Farm survey evidence from two contrasting districts in Uzbekistan. IAMO Discussion Paper, No. 153. IAMO, Halle (Saale).

Rozelle, S.-Swinnen, J. F. M. [2004]: Success and Failure of Reform: Insights from the Transition of Agriculture. Journal of Economic Literature, Vol. 42. No. 4. 404-456. o. https:// doi.org/10.1257/0022051041409048.

Swinnen, J. F. M.-Rozelle, S. [2006]: From Marx and Mao to the Market: The Economics and Politics of Agricultural Transition. Oxford University Press, Oxford, UK.

Tangermann, S.-Banse, M. [2000]: Central and Eastern European Agriculture in an Expanding European Union. CABI Publishing, Wallingford, Egyesült Királyság.

Timmer, M. P.-InklaAR, R.-O’Mahony, M.-van ArK, B. [2010]: Economic Growth in Europe: A Comparative Industry Perspective. Cambridge University Press, New York.

Von Cramon-Taubadel, S.-Loy, J.-P.-Meyer, J. [2006]: The impact of cross-sectional data aggregation on the measurement of vertical price transmission: An experiment with German food prices. Agribusiness, Vol. 22. No. 4. 505-522. o. https://doi.org/10.1002/agr.20100.

Zahorsky, T.-Pokrivcak, J. [2017]: Assessment of the Agricultural Performance in Central and Eastern European Countries. AGRIS on-line Papers in Economics and Informatics, Vol. 9. No. 1. 113-123. o. https://doi.org/10.7160/aol.2017.090110. 